\section{Role społeczne uczonych. Roman Jakobson i Polacy}

Danuta Ulicka

TEKSTY DRUGIE 2021, NR 2, S. 260-280

DOI: $10.18318 /$ td.2021.2.16 | ORCID: 0000-0001-6638-6661

\section{PamięciJacka Balucha}

\section{Fakt listowy}

Gdyby zgeometryzować przestrzeń nowoczesnego literaturoznawstwa teoretycznego i przedstawić ją w formie trójkąta o podstawie niemieckiej, którego trzy wierzchołki wyznaczają Rosja, Czechosłowacja i Polska, to Roman Jakobson znalazłby się w środku tej figury. I nie dlatego, że jego trzy kolejne żony to Rosjanka niemieckiego pochodzenia, Sonia Feldman, Czeszka Svatava Pírková i Polka Krystyna Pomorska.

O „planetarnych" osiągnięciach Jakobsona ${ }^{1} \mathrm{i}$ jego pozycji w humanistyce rosyjskiej i czeskiej napisano wiele. Niewiele natomiast - o szczególnych rolach, jakie odegrał wobec polskiej literaturoznawczej kultury naukowej².

1 Określenie Piotra Sawickiego z listu do Jakobsona z 9 sierpnia 1930, zob. Pražska škola v korespondenci. Dopisy z let 1924-1989, ed. M. Havránková, V. Petkevič, Univerzita Karlova v Praze 2014, S. 291.

2 Wspominali o tym Stefan Żółkiewski (Roman Jakobson (11 października 1896 - 18 lipca 1982, „Pamiętnik Literacki” 1983 z. 1) i Maria Renata
Artykuł powstał w ramach projektu NCN 2014/13/B/ HS2/00310 "Wiek teorii. Sto lat polskiej myśli teoretycznoliterackiej".

Danuta Ulicka - prof. zw. dr hab., kierownik Zakładu Poetyki, Teorii Literatury i Metodologii Badań Literackich w ILP UW, wiceprzewodnicząca KNoL PAN. Autorka książek Ingardenowska filozofia literatury. (1992); Granice literatury i pogranicza literaturoznawstwa (1999), Literaturoznawcze dyskursy możliwe (2007), Słowa i ludzie (2014), inicjatorka i redaktorka książek zbiorowych (ostatnio: Wiek teorii, Sto lat nowoczesnego literaturoznawstwa polskiego, 2020), tłumaczka rosyjskiej myśli humanistycznej XX wieku (ostatnio Jakobsona). 
Jak zaniedbany to fragment jego biografii intelektualnej, wymownie świadczy zapis w archiwum w MIT: „Oprócz materiałów anglojęzycznych zgromadzono także źródła po francusku, niemiecku, rosyjsku, czesku i w innych językach słowiańskich"”3, choć listów po polsku od i do uczonych polskich nie brakuje...

Był tej kultury autentycznym znawcą i ambasadorem. To dzięki niemu w ogóle jako tako zaistniała w świecie. W odróżnieniu bowiem od Rosjan, Czechów i Słowaków, niestrudzenie rozpowszechniających „swoje” teorie, Polacy sami o to nie zadbali. Jakobson nie musiał więc przekonywać „o pionierskim znaczeniu Praskiego Koła Lingwistycznego"4. Podjął się natomiast roli propagatora teorii polskiej, którą wprowadzał do świadomości międzynarodowej od końca lat 20. XX wieku, kiedy po raz pierwszy pisał o Janie Baudouinie de Courtenay ${ }^{5}$. Nieodmiennie podkreślał jej równorzędność z rosyjską i czeską, a często - prekursorstwo, jak w wypadku kazańskiej szkoły polskiego językoznawstwa ${ }^{6}$. Cenił zwłaszcza Mikołaja Kruszewskiego, którego rozróżnienie dwóch typów związków językowych uznał za zaczyn własnej koncepcji metonimii i metafory ${ }^{7}$. Odkrywał dla świata koncepcje tak zapomniane, jak Pierwsze zasady gramatyki jezzyka polskiego (1822) Józefa Mrozińskiego, które podnosił - „stanowczo wymagają nowego wydania, niezbędnego dla historii lingwistyki, a szerzej - dla historii myśli naukowej"8.

Mayenowa (Roman Jakobson: wspomnienie, „Pamiętnik Literacki” 1983 z. 1), ale obszerniej bodaj tylko Michał Głowiński (Roman Jakobson w Polsze, w: Roman Jakobson: tieksty, dokumienty, issledowanija / Texts, documents, studies, ried. H. Baran, S.I. Gindin, RGGU, Moskwa 1999).

3 Massachusetts Institute of Technology, Institue Archives and Special Collections, Guide to the Papers of Roman Jakobson, https://libraries.mit.edu/archives/research/collections/collections-mc/mc72.html\#toc (20.08. 2019).

4 List do Josefa Vaschka z 22 listopada 1948, cyt. za: Pražska škola v korespondenci, s. 449.

5 R. Jakobson Jan Baudouin de Courtenay, ",Slavische Rundschau” 1929 Band I, Nr. 10.

6 R. Jakobson Kazańska szkoła polskiej lingwistyki i jej miejsce w światowym rozwoju fonologii, „Biuletyn PT)" 1960, s. 3-34.

7 R. Jakobson Znaczenije Kruszewskogo w pamiati nauki o jazykie, w: tegoż, Selected Writings, vol. 2: Word and language, The Hague-Paris 1971, s. 429-449 (dalej SW z podaniem numeru tomu); po polsku jako przedmowa do: M. Kruszewski Wybór pism, red. .. Kuryłowicz, Zakład Narodowy im Ossolińskich i Wydawnictwo PAN, Wrocław 1967.

8 Jazykowiedczeskije boi gienierała Mrozinskogo: pamjatka i napominanije, w: SW 2, s. 388; cyt. za przekładem polskim Józef Mroziński - jenerał-językoznawca. Pamiq̨tka i przypomnienie, w: R. Jakobson W poszukiwaniu istoty języka. Wybór pism, wybór, red. i wstęp M.R. Mayenowa, PIW, Warszawa 1989, t. 2, s. 20. 
Umieszczał tę propagowaną polską teorię w przestrzeni środkowoi wschodnioeuropejskiej, krążąc - także dosłownie - pomiędzy sąsiadującymi obszarami, tłumacząc je na siebie nawzajem i splatając ze sobą na nowo'. Uzmysławiał, że na nich właśnie narodziły się nowoczesna lingwistyka i teoria literatury, zanim zaczęły wędrować po globie. Niedługo po przybyciu do USA, w 1943 roku, na wykładzie wygłoszonym w The Polish Institute of Art and Sciences mówił:

Młodzi Rosjanie, Czesi, Słowacy i Polacy byli niestrudzonymi pionierami językoznawstwa strukturalnego zarówno w fonologii, jak w badaniach nad językiem poetyckim. To nowe pole, które odkryli [...], stanęło otworem: w jego eksploracji nie było śladu rutyny $[\ldots] .^{10}$

Eksponował przy tym nie tylko dojrzałe strukturalistyczne, ale wręcz semiotyczne nastawienie badaczy czeskich i polskich:

Wyjściowa, zdecydowanie mechanistyczna koncepcja formy i funkcji spowodowała głęboki kryzys w szkole formalnej, który okazał się najbardziej produktywny w nauce polskiej i czesko-słowackiej, gdzie formalizm rozwinął się w wyrafinowany strukturalizm. Niedawne rozprawy Koła Praskiego (J. Mukarovský etc.) i grupy polskiej (M. Kridl, F. Siedlecki etc.) rozszerzyły horyzonty poetyki i wszelkiej „nauki o znakach” (semiotyki), doprowadzając do nowej owocnej symbiozy trzech słowiańskich inspirujących trendów."

Nawiasem mówiąc, do takiego miejsca polskiej teorii musiał niekiedy przekonywać samych Polaków. Wykład w PIASA był polemiczny wobec politycznej orientacji Instytutu, dla którego wszystko, co rosyjskie, w tym tzw. polski formalizm reprezentowany przez międzywojenne koła polonistów z grupy warszawsko-wileńskiej Stefana Żółkiewskiego i Manfreda Kridla, trąciło bolszewizmem. W tym kontekście tytuł „Polsko-rosyjska współpraca w nauce o języku" musiał brzmieć prowokująco.

9 Na ten temat por. M. Waldstein The Soviet empire of signs: a history of the Tartu School of Semiotics, VDM Verlag, Saarbrücken 2008, s. 85. science of language, w: SW 2, s. 454. 
O doniosłości teorii polskiej Jakobson przekonywał świat niestrudzenie. Piętnaście lat po wykładzie w PIASA informował Marię Renatę Mayenową listem z 24 stycznia 1959 roku:

Miałem pod koniec grudnia obszerny wykład na dorocznym zjeździe Modern Language Association w Nowym Jorku o lingwistyce i poetyce, w którym podkreślałem między innymi, że o ile w latach dwudziestych Rosja, a w trzydziestych Czechosłowacja, tak teraz Polska odgrywa w tej dziedzinie najdonioślejszą rolę ${ }^{12}$.

I właśnie li s ty Jakobsona najlepiej dokumentują odgrywane przez niego role. Zwykle taką rangę przypisuje się pamiętnikom, już w latach 20. uznanym przez polskich socjologów za najlepsze źródła do poznania świadomości społecznej i indywidualnej ${ }^{13}$. W wypadku Jakobsona wspomnienia takiej funkcji nie pełnią. Z jego pamiętników mówionych nie da się odtworzyć sceny życia i odgrywanych na niej i spoza niej ról14. Nie lubił zresztą gatunku wspomnień, świadomy jego podejrzanego statusu ${ }^{15}$.

Dla historii intelektualnej, zwłaszcza tej niejawnej, ukrytej za kulisami, listy to w ogóle bezcenny materiał. Są świadectwem bardziej wiarygodnym niż autobiografie, dzienniki i pamiętniki, tam bowiem można napisać wszystko i wszystko odwołać. Korespondencja sporządzana na gorąco nie daje takiej swobody, choćby ze względu na adresata, który zwykle zna kontekst wypowiedzi i jej bohaterów. Ponadto list, jeśli się zachował, jest twardym faktem kulturowym, wokół którego można oczywiście konstruować opowieści, ale którego zmienić ani usunąć nie sposób. I jest wymowne, że oba

12 Polska Akademia Nauk Archiwum w Warszawie (dalej APAN), sygn. III-403, poz. 25, k. 9. Cytowany fragment został odnaleziony przez prof. Marię Prussak, której dziękuję za podzielenie się odkryciem i udostępnienie korespondencji między Mayenową i Jakobsonem. Wykład zatytułowany "Linguistics and poetics" Jakobson wygłosił 27 grudnia 1958 roku.

13 F. Znaniecki, W.I. Thomas The Polish peasant in Europe and America, vol. 1-5, Gorham Press, Boston 1918-1920; F. Znaniecki The Method of sociology, Farrar \& Rinehart, New York 1934.

14 R. Jakobson Mój futuryzm. Wspomnienia, listy, szkice, wiersze, proza, red. B. Jangfeldt, przeł. D. Ulicka, PIW, Warszawa 2020; R. Jakobson, K. Pomorska Dialogues, Cambridge University Press, Cambridge 1983.

15 Por. K. Pomorska The autobiography of a scholar, w: Language, poetry and poetics: the generation of the 189os Jakobson, Trubetzkoy, Majakovskij. The First Roman Jakobson Colloquium at the Massachittes Institute of Tehnology, October 5-6, 1984, ed. by K. Pomorska et al., De Gruyter, BerlinNew York-Amsterdam 1987, s. 4. 
wspomnieniowe świadectwa pracy i dni pozostawione przez Jakobsona mają charakter dialogów, tak właśnie jak list, tyle że w odróżnieniu od dialogu listownego - "gadanych".

Korpus korespondencji Jakobsona z polskimi literaturoznawcami zachował się tylko częściowo. O wielu listach wiemy jedynie, że były ${ }^{16}$. Przepadły bezpowrotnie, być może spłonęły, jak „wszystko, co przyszło spalić w Brnie w noc na 15 marca 1939 na oczach zezwierzęconej sfory sudeckich nazistów"17. Wśród ocalałych wyjątkowe miejsce zajmuje zbiór listów między Jakobsonem i Mayenową. Jest obszerny i obustronny ${ }^{18}$. To nieczęsta sytuacja w nauce środkowo- i wschodnioeuropejskiej. Ale zbiór jest unikatowy także dlatego, że listy mają charakter równocześnie merytoryczny i prywatny. Dotyczą całej naukowej codzienności: spraw intelektualnych i organizacyjnych, przedsiębranych i planowanych prac, wspólnie inicjowanych konferencji, projektów badawczych i wydawniczych, o których się informowali i które nawzajem oceniali. Te - odsłaniają liczne role uczonego, niekiedy zakulisowe, ale odgrywane na co dzień oficjalnie. Listy dotyczą jednak również codzienności prywatnej, rodzinnej i towarzyskiej. Przekazywane w nich ciepłe, serdeczne wiadomości i plotki (o bliskich, o zdrowiu, o potrzebnych lekach, o wakacyjnych podróżach, o remoncie mieszkania, o drobnych niesnaskach środowiskowych, o kondycji psychicznej i przeżywanych lękach) wyróżniają je na tle korespondencji Jakobsona z innymi uczonymi, zwykle tylko profesjonalno-oficjalnej, wolnej od kłopotów i uciech dnia powszedniego. Krótko: korespondencja z Mayenową podbudowuje oficjalne fakty literaturoznawcze i zespala je z nieoficjalnymi. Laboratorium obojga uczonych - a oboje używali tego określenia - łączy się w niej z ich „kuchnią”.

16 Np. o korespondencji z Siedleckim, z której zachował się jeden jedyny list, a o pozostałych dowiadujemy się tylko z listów Siedleckiego, Kridla i Żółkiewskiego, lub o listach Nikołaja Trubieckiego i Kazimierza Wóycickiego, o których napomyka Siedlecki (F. Siedlecki Studia Wóycickiego nad wierszem a nowe prądy badawcze, "Życie Literackie” 1938 z. 1, przedruk. w: F. Siedlecki Pisma, zebrali i opracowali M.R. Mayenowa i S. Żółkiewski, PIW, Warszawa 1989, s. 210).

17 R. Jakobson List badacza polskiego, w: Literatura, komparatystyka folklor. Księga poświęcona Julianowi Krzyżanowskiemu, red. M. Bokszczanin, S. Frybes, E. Jankowski, PIW, Warszawa 1968, s. 666 . Listy Mayenowej do Jakobsona zdeponowane w Massachusetts Institute of Technology, Institute Archives and Special Collections (Collection 0072, Box 44, Folder 15; dalej MIT), datowane na lata 1946-1979, obejmują 65 jednostek. 
Ta wyjątkowość korespondencji wynika także stąd, że większość listów pisała „w imieniu profesora”, który jest „szalenie zajęty" ${ }^{\text {, }}$, ale „wybiera się z listem do Pani i pewnie co napisze podczas przerwy świątecznej”20, Krystyna Pomorska (trzecia żona Jakobsona, poznana w Polsce w 1958 roku, na zorganizowanej przez Mayenową konferencji w Krynicy). Tylko taka nadawczyni mogła w liście z 5 października 1963 roku dopisać postscriptum (do góry nogami, wyraźnie w pośpiechu): „Powiem plotkę: Taranowski się w pani kocha"21, czy też zapytać, co ma przywieźć, jeśli spotkają się w Mediolanie: „szczepionki, zastrzyki, szminkę?"22. Na wielu listach kilka słów dopisywał sam Jakobson, być może więc i inne przechodziły przez jego lekturę. W tym sensie jest ich pośrednim współautorem. W tych dopiskach również uderza ton prywatny („Kocham i przyjadę na początku września”23), niespotykany w korespondencji z innymi uczonymi.

O zażyłości Jakobsona i Mayenowej świadczą oczywiście formy honoryfikacyjne, zmieniające się wraz z upływem lat - z jej strony od "Głubokouważajemyj Gospodin Profiessor” po „Roman, kochany”. To rzecz zwyczajna i nie warto by o niej wspominać, gdyby nie zastrzeżenie Mayenowej do propozycji Jakobsona, by przeszli na „ty”: „nie mogę pisać po polsku po imieniu, bo to wymagałoby wypicia razem przynajmniej jeszcze dwóch litrów wódki". To „jeszcze” w liście z 9 kwietnia 1959 roku jest wymowne - stanowi wyraźnie aluzję do ich spotkania w Krynicy, którego aurę oficjalne sprawozdanie pomija ${ }^{24}$. Jeszcze bardziej znaczące dla zażyłości są hybrydy języka prywatnego i profesjolektu, które wskazują na nieodróżnialną bliskość przyjacielską i zawodową, na wspólny język i wyniesione ze wspólnych lektur wartości, cementujące wzajemne relacje ${ }^{25}$. Listy pozwalają więc odtworzyć collegium

19 Cyt. z listu opatrzonego datą 25 stycznia 196o, napisanego przez Pomorską do Mayenowej po polsku (APAN, sygn. III-403, poz. 25, k. 1).

Kartka pocztowa z 6 grudnia 1963 (APAN, sygn. III-403, poz. 25, k. 4).

APAN, sygn. Ill-403, poz. 25, k. 3 verso. Chodzi o slawistę, znanego świecie jako „Kiril Taranovsky".

List z 30 kwietnia 1974 roku (APAN, sygn. III-403, poz. 25, k. 35).

Dopisek Jakobsona na kartce pocztowej wysłanej do Mayenowej z Rzymu 16 maja 1967 roku (APAN, sygn. III-403, poz. 25, k. 17).

4 Zob. A. Okopieniowa, M. Głowiński Wykłady prof. Jakobsona w Krynicy, "Pamiętnik Literacki” 1959 Z. 1, s. 315-320.

W liście z 21 marca 1961 (MIT) pisanym przez Pomorską, odpowiadającym na list, w którym Mayenowa skarżyła się na nie najlepszą kondycję emocjonalną, nadawczyni zaznacza, że zdaje 
invisibile, które ostatecznie zawiązało się w latach 50., ale powstawać zaczęło jeszcze przed wojną.

Tylko o polityce oboje milczeli, a jeśli robili do niej aluzje, to zatrącające jedynie o politykę naukową. Nawet w 1968 roku nie zeszli na politykę państwową. Mogły o tym decydować względy cenzuralne (w PRL korespondencja zagraniczna podlegała inwigilacji nie mniej niż korespondenci), ale chyba nie tylko one, skoro w listach wysyłanych do USA do Kridla Mayenowa nie raz jawnie i ostro oceniała aktualną sytuację. Wydaje się, że o neutralizacji kontekstu politycznego rozstrzygała wyznawana przez oboje Weberowska idea nauki jako zawodu i powołania ${ }^{26}$. Polityka, jeśli do niej wkraczała, to pośrednio: $\mathrm{w}$ formie podejmowanych tematów badawczych, organizacji życia naukowego, scalania środowiska wokół określonych postaw, zatrudniania - jak Mayenowa w swojej Pracowni - pewnych osób. Jakobson natomiast porównywał swoją naukową aktywność polityczną do gry w szachy: „Przyglądasz się z ciekawością, współczujesz przegrywającemu, cieszysz się sprytnym posunięciem zwyciężającego. [...] Możesz nawet na chwilę przysiąść i wykonać kilka ruchów za któregoś z graczy. Oto moje nastawienie do dzisiejszej polityki"27. Ta neutralizacja, wynikająca z rozpoznania sceny i występujących na niej aktorów, była gestem świadomym - i oczywiście politycznym.

Oboje umieli zresztą odróżniać postawy polityczne koniunkturalne od rzeczywistych zaangażowań po stronie wartości leżących w centrum inteligenckiego etosu naukowego od lat ich międzywojennej młodości. Toteż oboje zawsze serdecznie pisali o Żółkiewskim. Jakobson w 1975 roku martwił się o zdrowie jego żony, oferując wszelką pomoc ${ }^{28}$ - tak jak w roku 1939 Żółkiewski martwił się o jego życie ${ }^{29}$.

sobie sprawę z jej „formy wewnętrznej” - zaznaczając wspólnotę komunikacyjną cudzysłowem i dodając na wszelki wypadek w nawiasie "w Humboldtowsko-Potebniańskim znaczeniu”.

M. Weber Nauka jako zawód i powołanie, w: Polityka jako zawód i powołanie, red. Z. Krasnodębski, przeł. P. Dybel, Znak i Fundacja im. Stefana Batorego, Kraków-Warszawa 1998. Weber przedstawił swoją koncepcję w roku 1917 w formie wykładu "Wissenschaft als Beruf".

Cyt. za: B. Jangfeldt Majakowski. Stawkq̨ było życie, przeł. Wojciech Łygaś, W.A.B., Warszawa 2010, s. 202.

List do Mayenowej pisany przez Pomorską z 13 grudnia 1975 (MIT, 0441). dalej LMAVB) zachował się list Żółkiewskiego do Kridla z 23 kwietnia 1939 (F. 115-258) z prośbą, by ten zwrócił się do Maksa Weinreicha, dyrektora wileńskiego Żydowskiego Instytutu Naukowego, o pomoc w uzyskaniu adresu członka Koła Praskiego, językoznawcy Pavla Trosta, w celu „ustalenia losów” Jakobsona. Korespondencja z Trostem została nawiązana i Żółkiewski 
Taka postawa narażała na podejrzenia, pomówienia i oskarżenia. Wobec Mayenowej sformułowała je m.in. Maria Rzeuska, jej wileńska koleżanka ze studiów i towarzyszka z Koła Polonistów założonego na USB przez Kridla. W liście do niego z 19 stycznia 1952 roku z ogromną niechęcią pisała o Mayenowej i „jej sojuszniczce Gienie” (Eugenii Krassowskiej - także studentce Kridla i członkini Wileńskiego Koła Polonistów, a po wojnie, od lat 50. do 70. włącznie, podobnie jak Żółkiewski wysokiej urzędniczce państwowej), zarzucając obu dwuznaczną pozycję polityczną ${ }^{30}$. Jakobson doświadczył takich pomówień nie tylko oficjalnie - oskarżony przez senacką komisję McCarthy'ego, która w 1953 roku rozpoczęła śledztwo w sprawie jego rzekomej działalności antyamerykańskiej. Podobne formułowali rosyjscy emigranci. Wlistopadzie 1956 roku Roman Grinberg, niegdyś dobry znajomy z lat uniwersyteckich, pisał do Edmunda Wilsona: „Leży u mnie na stole książka-monstrum [...] - książka stalinowska! [...] poświęcona ROMANOWI JAKOBSONOWI na jego 6o-lecie. [...] tak [...] kwitnie «kult jednostki»"31. Dla obojga oskarżenia formułowane przez niegdysiejszych przyjaciół musiały być bardziej dotkliwe niż ze strony władz. Dla nas - oświetlają kulisy sceny naukowej, i w Polsce, i w USA zastawionej czarno- (lub czerwono-) białymi dekoracjami.

Listy zarówno Jakobsona do Mayenowej, jak jej do niego są trójjęzyczne pisane odręcznie lub na maszynie po polsku, rosyjsku i angielsku. Jakobson znał polski już w latach studiów (gdy przybył do Pragi, nie znał natomiast czeskiego, ale znając polski, starał się jakoś sobie radzić, nie bez zabawnych potknięć) ${ }^{32}$, rozumiał polski doskonale i świetnie analizował polską poezję. Dopiero po latach zamerykanizował swoją polszczyznę. Na karteluszku (bez daty) zostawionym w IBL dla Mayenowej napisał: „Byłem tu. Chciałem mieć obiad z tobą". Okres amerykański wyraźnie odcisnął piętno na najgłębszym

dowiedział się, że ")akobson wyrwał się z więzienia i jest w Kopenhadze" (o czym poinformował Kridla listem z 3 maja 1939, tamże). Zachowało się także podziękowanie Jakobsona adresowane do Żółkiewskiego za przesłaną mu książkę Kultura, socjologia, semiotyka literacka - „o tak szerokich horyzontach" (Biblioteka Narodowa, Archiwum Stefana Żółkiewskiego, teczka 1: korespondencja, rps. akc. 13991; za podzielenie się tym odkryciem dziękuję Piotrowi Sidorowiczowi).

Listy do Kridla są zdeponowane w Rare Books \& Manuscripts Library, Columbia University, Manfred Kridl Papers (dalej RBML z podaniem numeru pudła i jeśli są - pozostałych informacji archiwalnych). Przywoływany list: RBML, Box 4.

31 R. Jangirow Roman Grinbierg i Roman Jakobson. Matieriały k istorii wzaimootniszenij, w: Roman Jakobson: tieksty, dokumenty, issledowanija, s. 203. 
poziomie kompetencji językowej - na składni. Ani po polsku, ani po rosyjsku nie da się powiedzieć „mieć [z kimś] obiad”.

\section{Jakobson w Polsce}

Jakobson był w Polsce ledwo (lub aż) dziewięć razy. Po raz pierwszy w styczniu 1958 roku, czyli zaraz na początku swoich podróży naukowych po krajach „bratniego obozu”33. Najbardziej pamiętny był jednak o pół roku późniejszy (16-2o października) pobyt w Krynicy na ogólnopolskiej konferencji teoretycznoliterackiej. Jakobson przyjechał do górskiej miejscowości na zaproszenie i dzięki staraniom Mayenowej (którą osobiście poznał we wrześniu 1958 roku na IV Kongresie Slawistycznym w Moskwie), wspieranej przez Żółkiewskiego, jego i jej pośredniego (korespondencyjnego) znajomego z lat międzywojennej współpracy grupy warszawsko-wileńskiej, wtedy prezesa Warszawskiego Koła Polonistów, a w latach 50. ministra szkolnictwa wyższego. Wówczas w Krynicy odbyła się światowa premiera przyszłej Poetyki w świetle językoznawstwa zaprezentowanej jako wykład „The Linguistic Aspect of Poetics". W 1959, bodaj w związku z wyborem do PAN, Jakobson wykładał w Warszawie, Krakowie i Poznaniu. Wydarzeniem w skali międzynarodowej była zaś Międzynarodowa Konferencja Poetyki w Warszawie, 18-27 sierpnia 1960 roku. Mayenowa i Jakobson przygotowywali ją - oczywiście korespondencyjnie - wspólnie, ustalając listę gości, zdobywając ich adresy, sondując możliwości przyjazdu i wymagane do wiz dokumenty, negocjując porządek obrad i czas przydzielony referentom ${ }^{34}$. Zorganizowane przez nich dziewięciodniowe obrady zgromadziły uczonych z dwunastu krajów, w tym takie autorytety, jak Thomas Sebeok, Dmitrij S. Lichaczow, Victor Erlich, Roger Caillois, Iván Fónagy, Bruno Markwardt, Abraham A. Moles, Pavel Trost i Josef Hrabák, znani obojgu z międzywojnia, oraz ich intelektualni spadkobiercy, Lubomir Doležel i Jiří Levýs ${ }^{35}$. Jakobson wygłosił wtedy

10 stycznia 1958 w Warszawie Jakobson brał udział w konferencji na temat dawnej polskiej leksykologii, a 20 stycznia w Poznaniu w ogólnopolskiej konferencji poświęconej językoznawstwu ogólnemu.

Notabene kapitalnie brzmi dziś zmartwienie Mayenowej, że wobec dużej liczby zgłoszeń "wypowiedź referenta nie powinna trwać dłużej niż 30-45 minut" (MIT, list niedatowany, ale z treści wynika, że pisany po 7 lutego 1960 roku).

35 Nie wszyscy z wymienionych uczonych przybyli na konferencję, ale wszyscy przesłali referaty zamieszczone w pokonferencyjnej księdze Poetics. Poetyka. Poetika, t. 1, PWN, Warszawa 1961. 
referat „Poezija grammatiki i grammatika poezji” - także ta kanoniczna rozprawa miała więc polską prapremierę. W następnym roku 21-29 września Jakobson był w Jabłonnie na Międzynarodowej Konferencji Poetyki, gdzie zaprezentował „Problems of parallelism in folk poetry” (a przy okazji wygłosił też wykład na uniwersytetach warszawskim i łódzkim na temat „Old Church Slavonic poetry”). W dniach 24-31 sierpnia 1964 roku uczestniczył w międzynarodowej konferencji poświęconej metryce słowiańskiej i ogólnej w Warszawie, na której 25 sierpnia wygłosił referat „O wyrazach jednosylabowych w wierszu rosyjskim” $\mathrm{i}$ być może jeszcze trzy inne prelekcje („O stosunku między znakami wizualnymi i audytywnymi”, „Moskiewskie Koło Lingwistyczne” $i$,Specyficzne właściwości akcentu w porównaniu z innymi elementami prozodycznymi") ${ }^{36}$. W sierpniu (24-28) roku następnego uczestniczył w Warszawie w International Semiotics Symposium. W 1966 na trwającym od 13 do 18 września Międzynarodowym Kolokwium Semiologicznym w Kazimierzu nad Wisłą wygłosił referat "Signatum and designatum". Po raz ostatni oficjalnie był w Polsce w dniach 21-27 sierpnia 1973 roku na VII Kongresie Slawistów.

Zważywszy na niezwykle intensywny udział Jakobsona w światowym życiu naukowym, było tego niemało. Ile zachodu wymagało przygotowanie każdej z wizyt, świadczą listy z tych lat wymieniane z Mayenową. Pomagali jej wszechpotężni wtedy Żółkiewski i Kazimierz Wyka, dyrektor IBL. Jakie znaczenie miał ten Instytut, Jakobson podkreślał przy różnych okazjach, nawet kiedy nie było to konieczne. Na przykład wspierając prośbę Mayenowej, stypendystki Institute of International Education, o specjalny magnetofon, zaznaczał dobitnie: „Mogę zapewnić, że przez ostatnie kilkanaście lat prace i publikacje tego Instytutu wniosły do badań nad poetyką i styczną z nią lingwistyką więcej niż wszystkie inne europejskie instytuty razem wzięte"37. Listy poświadczają więc także amerykańską i polską zakulisową politykę naukową, o której milczą historie nauki. A przy okazji demaskują PRL-owską politykę oficjalną: jej niekompetencje i - szczęściem - brak rozeznania. Dzięki niewiedzy decydentów, kto zacz Dmitrij Lichaczow czy Miroslav Červenka, uczeni z krajów bloku dostawali zgodę na przyjazdy naukowe. Ich "poprawne” obywatelstwo niejako gwarantowało zbieżność z obowiązującą polityką ${ }^{38}$.

36 Różne źródła podają odmienne tytuły wystąpień i inne daty.

37 List do Marianne Davis z 11 maja 1962 roku (MIT).

38 Stanisław Pomorski przytacza zabawną historię, jak to Jerzy Kuryłowicz miał przekonać Henryka Jabłońskiego oponującego przeciw wyborowi Jakobsona na członka PAN z powodu artykułu 
Wizyt oficjalnych było więc tylko lub aż dziewięć. Co jednak istotne - były to wizyty kontynuujące kontakty listowne z nowoczesnym polskim literaturoznawstwem, zadzierzgnięte w połowie lat 30. Wtedy właśnie w trybie wymiany korespondencyjnej zawiązała się niewidzialna wspólnota, która dopiero w połowie poodwilżowych lat 50. mogła się uwidocznić, a jej aktorzy wyszli na proscenium.

\section{Listowne początki zażyłości}

Jakie naprawdę były pierwsze kontakty Jakobsona z polskimi badaczami, jest chyba nie do odtworzenia. Nie udało się w każdym razie ustalić, kim byli spotkani w Moskwie w połowie 1920 roku „dwaj młodzi polscy uczeni”, którzy „jako komuniści zostali w końcu lat 30. «niesłusznie zlikwidowani»”. To oni właśnie mieli spowodować, że Jakobson - jak się okazało, na stałe opuścił Rosję:

Jeden z nich zaproponował mi wyjazd do Pragi w składzie misji Czerwonego Krzyża. Misja miała za zadanie przeprowadzić repatriację byłych rosyjskich żołnierzy, którzy znaleźli się w Czechach jeszcze za czasów austro-węgierskich, oraz podjąć próbę nawiązania kontaktów dyplomatycznych z Czechosłowacją. „Zna pan przecież język czeski?”Wyjaśniłem, że znam [...]. - „Gdzie my znajdziemy kogoś takiego!"39

Nikt, jak na razie, nie pasuje do tej roli.

Jest natomiast pewne, że środowisko literaturoznawców, z którymi Jakobson wszedł w kontakt korespondencyjny, intensywny zwłaszcza w połowie lat 30., obejmowało członków studenckich naukowych kół polonistów z Warszawy i Wilna. Należeli do nich Mayenowa i Żółkiewski, a nadto z wymienianych w listach warszawiacy: Franciszek Siedlecki, Dawid Hopensztand i Kazimierz Budzyk, oraz wilnianie: Kridl i Krassowska.

opublikowanego przez "Rude Pravo", w którym uczony został uznany za „eksperta amerykańskich tajnych służb", pytając: „Profesorze Jabłoński, czy może nam pan powiedzieć, co to jest «Rude Pravo»? Czy to periodyk lingwistyczny? «Nie, to oficjalny organ Komunistycznej Partii Czechosłowacji» - odparł Jabłoński. «Jeśli tak, to zmieniam zasady postępowania w sprawie»", odparował Kuryłowicz. Cyt. za: S. Pomorski Remembering Roman Osipovič /akobson, s. 267. 
Po raz pierwszy Jakobson zetknął się z tym „światem polskich nowatorów" za sprawą Leonarda Podhorskiego-Okołowa ${ }^{40}$, pośrednio związanego z kołem warszawskim i stowarzyszoną z nim grupą Skamandra. Podhorski posłał Jakobsonowi listownie swoje artykuły z 1925 i 1926 roku $^{41}$, w których powoływał się na jego rozprawę O czeszskom stichie prieimuszczestwienno w sopostawleniiz russkim (1923), prosząc o arbitraż w sporze z Kazimierzem Nitschem, polemizującym z ujęciem autora i w ogóle z rymowaniem skamandrytów. Jakobson arbitrażu się nie podjął, uczciwie doceniając argumenty Nitscha, jak pisał po latach ${ }^{42}$, być może także zrażony wtedy „rymowankami” Podhorskiego, który nie tylko wyznawczo zastosował jego pomysły, lecz nawet powielił ogólne konkluzje.

W liście do Juliana Krzyżanowskiego Jakobson wspomina: „Niedługo potem w grupie poetów Skamandra, goszczących w Pradze, spotkałem Juliana Tuwima. Przy lampce tokaju w staromiejskiej knajpce zawiązała się między nami przyjaźn’" ${ }^{\prime 3}$. Nie podaje jednak, że korespondencyjną znajomość z Tuwimem zawarł już wcześniej, zachęcając go do odwiedzenia Pragi w liście z 13 kwietnia 1929 roku, będącym odpowiedzią na list Tuwima do niego ${ }^{44}$. List dotyczył przede wszystkim Tuwimowych przekładów z poezji rosyjskiej. Jakobson prosił o przesłanie mu gotowego już tłumaczenia Obłoku w spodniach Majakowskiego ${ }^{45} \mathrm{i}$ Jeźdźca miedzianego Puszkina, nad którym Tuwim pracował od 1927 roku, obiecując napisanie artykułu na temat jego sztuki translatorskiej i zapraszając go do współpracy ze „Slavische Rundschau”. Deklarował

40 Jakobson pisze o tym w liście do Juliana Krzyżanowskiego, opublikowanym jako artykuł List badacza polskiego, s. 664). Nie udało się ustalić, z którego roku był list Podhorskiego-Okołowa.

41 L. Podhorski-Okołów O rymowaniu, "Skamander" 1925 z. 37; W obronie "nowych rymów”, "Skamander" 1926 z. 44/46.

Odniósł się do nich w 1968 roku, publikując List badacza polskiego (s. 655-666). Może też nie chciał urazić Nitscha, którego mógł poznać w 1930 roku na Międzynarodowej Konferencji Fonologicznej w Pradze.

43 R. Jakobson List badacza polskiego, s. 666. W podobnej tonacji jako wspaniałego kompana i „cygana" Jakobsona wspomina nowojorskie spotkanie w 1943 roku Tuwim (J. Tuwim Listy do przyjaciół-pisarzy, oprac. T. Januszewski, Czytelnik, Warszawa 1979, s. 438).

44 Nie udało się odnaleźć listu Tuwima do Jakobsona. List Jakobsona, odnaleziony przez Artura Hellicha, zachował się w archiwum Muzeum Literatury im. Mickiewicza w Warszawie, Dział Rękopisów, sygn. 3075, t. 11 (J.), k. 2-3.

45 Przekład ukazał się w 1923 roku w warszawskiej oficynie Philobiblon, z niezwykłą okładką Jana Tschicholda. 
również: „Z ogromną przyjemnością przyjechałbym do Warszawy” - co udało mu się dopiero dwadzieścia lat później.

Z listu wynika, że Jakobson zdawał sobie sprawę z sytuacji Tuwima polskiego Żyda i tłumacza-propagatora literatury rosyjskiej, w tym „bolszewickiej" ${ }^{46}$. O tym zapewne rozmawiali potem w Nowym Jorku, dokąd Jakobson dotarł w ostatnim, szóstym etapie swojej emigracyjnej tułaczki w 1941 roku, a Tuwim, także po kolejnych ucieczkach przed falami nazizmu, w 1942. Obu pasjonowały zarówno praktyczne, jak teoretyczne kwestie sztuki przekładu, wtedy zapewne przede wszystkim Stowa o wyprawie Igora, przez skamandrytę tłumaczonego na polski, a przez filologa rosyjskiego od lat analizowanego i przygotowywanego do wielojęzycznej edycji. Dla Tuwima już po pierwszym spotkaniu w Pradze Jakobson był nie tylko wybitnym uczonym, ale i „słowowiedem”, a Tuwim dla Jakobsona - pierwszym poetą nowoczesnej Polski. Musiał mu przypominać początki własnej biografii naukowo-artystycznej: moskiewską młodość spędzoną w towarzystwie malarzy, poetów i „teoretyków pozarozumowych" ${ }^{47}$. Bliskie zapewne były mu przekonania Tuwima, który sam siebie mianował (w wierszu Poezja z 1918 roku) "pierwszym w Polsce futurystą", o powielaniu dźwiękiem znaczenia ${ }^{48}$, Tuwimowe „chlebnikowskie” glosolalia, „teoretyczne fantasmagorie”, które snuł w Poezji, i „fantazje słowotwórcze" roztaczane w Zieleni (1936), zbieżne ze „szkłowskimi” zasadami języka poetyckiego jako zapisu wielozmysłowej percepcji świata, której eksponentami są deformacje i udziwnienia, obnażające formę wewnętrzną słowa. Nie dziwi więc, że zadedykował Tuwimowi wiersz napisany w Nowym Jorku w 1943 roku dnia 20 fantastycznego miesiąca martobria, w którym utrwalał spotkanie z nim i z "panną Stefą", czyli żoną poety:

Domowe życie, ech, jak dyluwialnie cuchnie, Rodzinnej chętnie umknę lianie.

46 Zob. P. Mitzner Obcy wśród swoich. Julian Tuwim i rosyjscy emigranci, „Acta Universitatis Lodziensis. Folia Polonica" $2014 \mathrm{nr} 4$.

47 Zob. R. Jakobson Mój futuryzm, s. 69.

48 „Dźwięk i znaczenie” to jeden z najważniejszych tematów rozważań Jakobsona, nurtujących go od najwcześniejszych lat, jeszcze moskiewskich. Powracał stale w korespondencji z Mayenową, która nieodmiennie wypytywała go o pracę nad poświęconą tej problematyce rozprawę - ostatecznie sfinalizowaną w roku 1979 (R. Jakobson, L. Waugh The sound shape of language, De Gruyter Mouton, Brighton 1979). Tuwim uchwycił cały problem w drugim wersie Zieleni: "O zieleni można nieskończenie / Powielając dźwiękiem jej znaczenie". 
Zróbmy burzliwy szabas więc, Tuwimie,

Umoczmy w winie chleb, Julianie.

Wzniećmy więc bunt, tak po przyjacielsku,

A będę jak lipcowa noc pijany,

A nas - tu klnę się na tradycje Lefa -

Pokocha jeszcze czulej panna Stefa.

\section{0 marcopada $43 \quad \operatorname{Roman}^{49}$}

Tyle mówią listy i ocalałe dokumenty. Jakkolwiek było, faktem jest, że to właśnie Tuwim i Podhorski-Okołów zostali zaproszeni do udziału w przygotowywanej przez „polskich nowatorów”, jak ich nazwał Jakobson, z grupy warszawsko-wileńskiej ${ }^{50}$ księgi Prac ofiarowanych Kazimierzowi Wóycickiemu. On sam także został do niej zaproszony.

Pomysł na księgę zrodził się w połowie lat 30. Jak wynika z listów Siedleckiego i Kridla z 1936 roku, warszawiacy z inicjatywy Siedleckiego rozpoczęli korespondencję z prażanami ${ }^{51}$. W zamyśle Siedleckiego Prace miały być zbiorem studiów „badaczy polskich i obcych, poświęconych problematom teorii literatury i językoznawstwa"52. Wydana w 1937 roku księga była wyjątkowa: przygotowana wspólnym, polsko-rosyjsko-czeskim wysiłkiem,

49 Wiersz, napisany po rosyjsku, a odnaleziony przez Artura Hellicha w Muzeum Literatury w Warszawie w Dziale Rękopisów (sygn. 3168) w przekładzie Przemysława Pietrzaka. Fantastyczny miesiąc "marcopad" pochodzi z Gogola Pamiętnika szaleńca (albo wariata). Utwór, utrzymany w stylu charakterystycznym dla Jakobsonowskich wierszy żartobliwych, ma ciekawy układ rymów: „pijany” (p'jan) rymuje się z „Roman”, niejako dopełniając podpis.

Piszę jedynie o pierwszych kontaktach Jakobsona z nowoczesnymi literaturoznawcami, pomijając językoznawców, których znał wcześniej (np. Wiktora Porzezińskiego). Zapewne jakieś kontakty utrzymywał także z polskimi folklorystami. W Polsce debiutował wszak w 1931 artykułem w periodyku "Lud Słowiański” wspólną pracą z Piotrem Bogatyriowem K problemie razmieżywanija fołkłoristiki i litieraturowiedienija („Lud Słowiański” 1931 t. 2, s. 230-233). W wykładzie wygłoszonym na Uniwersytecie Masaryka w Brnie w 1935 roku informował o tworzonym w Polsce ruchu strukturalistycznym, a za "polskich formalistów” uznał jeszcze Kazimierza Wóycickiego i Tadeusza Zielińskiego. Zob. R. Jakobson Formalistická škola a dnešní literární věda ruska, ed. T. Glanc, Academia, Praha 2005, s. 14, 98 oraz 33, 62). Zielińskiego wymienił także w Dialogues, szczególnie ceniąc jego pracę o fabułach (O sintagmach w driewniegrieczeskoj komiedii, "Żurnał Ministierstwa narodnogo proswieszczenija”, Sankt Pietierburg 1885, s. 133-242), którą uznał za prestrukturalistyczną.

51 Siedlecki do Kridla, list z 25 marca 1936 (LMAVB, F. 115-269).

M. Kridl Boje Wilna i Warszawy o nowq̨ naukę o literaturze, „Pamiętnik Literacki” 1957 Z. 2. 
przypieczętowywała powstanie i funkcjonowanie literaturoznawczego trójkąta, w którym rodziła się nowa dyscyplina - teoria literatury. Zgromadziła uczonych z Praskiego Koła Lingwistycznego i przebywających w Pradze emigrantów rosyjskich, wywodzących się z Koła Moskiewskiego, oraz liczną grupę badaczy polskich starszego i najmłodszego pokolenia, reprezentujących wszystkie ówcześnie żywe w Polsce orientacje literaturoznawcze. Zabrakło bodaj tylko psychoanalizy i fenomenologii, bo Roman Ingarden, zaproszony do udziału w przedsięwzięciu, ostatecznie nie nadesłał tekstu ${ }^{53}$. Wśród autorów zamieszczonych rozpraw znaleźli się Roman Jakobson, Josef Hrabák i Nikołaj Trubiecki; zaproszenie wystosowano także do Jana Mukařovskiego, który „z żalem” w księdze nie uczestniczy ${ }^{54}$. Księga była p i e r w s z y m w sąsiedztwie kolektywnym przedsięwzięciem międzynarodowym w takiej skali. Kontynuowała je w latach 6o.-80. seria prac bezprecedensowego w Europie Środkowej i Wschodniej zespołu Słowiańska Metryka Porównawcza, który powstał z inicjatywy Mayenowej, wzorującej się na komparatystycznych pracach Jakobsona - co sama wielokrotnie podkreślała ${ }^{55}$.

Jakobson zamieścił w Pracach rozprawę Z zagadnień prozodii starogreckiej pisaną w Brnie w kwietniu 1937 roku. Mayenowa - jako Rachela Kapłanowa - artykuł Wsprawie tendencji w powieści realistycznej. Pośrednio poznali się więc dziesięć lat przed pierwszymi listami i dwadzieścia lat przed spotkaniem twarzą w twarz, choć Jakobson zapewne nie kojarzył, że Kapłanowa z księgi dla Wóycickiego to Mayenowa ${ }^{56}$.

Nazwisko tłumacza rozprawy Jakobsona pomieszczonej w Pracach nie zostało podane, ale z Listu badacza polskiego wynika, że był to Siedlecki. Wtedy też Jakobson zaczął żywiej interesować się działaniami i publikacjami polskich badaczy. Kilkukrotnie zwracał się do Siedleckiego z prośbą o przysłanie mu

Ingarden usprawiedliwiał się brakiem pomysłu godnego osoby obdarowywanej $\mathrm{i}$ - „proszę się ze mnie nie śmiać" - brakiem natchnienia; list Ingardena do Kridla z 22 kwietnia 1937 (LMAVB, F. 115-261, k. 3 recto).

54 Tak podaje Pavel Trost: Z problemů poetiky, "Slovo a slovesnost” 1939 R. 5, s. 59-61.

55 Bodaj po raz pierwszy w liście z 25 stycznia 1959, w którym pisała do Jakobsona, że chciałaby "na wzór jego Kernel" (chodzi o The kernel of comparative Slavic literature „Harvard Slavic Studies” 1953), a zapewne także innych prac z wczesnych lat 50., stworzyć zespół do badań słowiańskiej poetyki porównawczej. po wojnie liście do niego. List nie jest datowany; Kridl dopisał na nim datę „12.III.46", prawdopodobnie otrzymania pisma (RBML, Box 3). 
„polskich prac z zakresu literaturoznawstwa" ${ }^{57}$. Współpraca rozwijała się chyba bardzo dobrze. Na początku 1937 roku Siedlecki informował Kridla, że Jakobson poważnie rozważa podjęcie systematycznych współdziałań Praskiego Koła Lingwistycznego z Warszawskim Kołem Polonistów ${ }^{58}$. Proponował Siedleckiemu m.in. roczny pobyt w Pradze. Siedlecki propozycji nie przyjął „ze skromności", jak pisze Jakobson, uznawszy, że jeszcze nie dojrzał do intelektualnych współdziałañ ${ }^{59}$.W tym samym czasie Jakobson złożył także młodym polskim uczonym propozycję publikowania w periodyku Koła „Slovo a slovesnost". Były tam już recenzowane rozprawy Siedleckiego ${ }^{60}$. W odpowiedzi na propozycję Jakobsona Siedlecki - jak pisał do Kridla - „pchnął” na łamy czasopisma artykuł Budzyka ${ }^{61}$.

Jest oczywiście zbiegiem okoliczności, ale symbolicznym, że pierwszy list Mayenowej do Jakobsona został wysłany właśnie z Pragi.

Kolejną okazją do regularnych kontaktów korespondencyjnych między "polskimi nowatorami” a Jakobsonem stała się przygotowywana obszerna antologia prac rosyjskich formalistów. Poprzedzał ją wstęp Kridla, a zamykało posłowie metodologiczne Żółkiewskiego i przeglądowo-historyczne studium Hopensztanda Formalizm rosyjski jako prąd naukowy - "na jakie 10 arkuszy"62. Siedlecki stale konsultował wybór rozpraw z Jakobsonem. To był, wedle wspomnienia tego ostatniego, drugi temat ich niezachowanych listów ${ }^{63}$. Antologia została wydrukowana na początku września 1939 roku. W pierwszych dniach wojny „cały jej nakład, jeszcze niezbroszurowany, spłonął na pl. Bankowym,

Siedlecki do Kridla, list z 25 marca 1936 (LMAVB, F. 115-269). Jakobson prośby nieraz ponawiał, m.in. liście do Kridla z 28 listopada 1948 roku, w którym pytał go, czy przywiózł jakieś interesujące książki z Polski, „And particularly the publications of the Kolo” (RBML, Box 1).

Siedlecki do Kridla, list z 3 marca 1937 (LMAVB, F. 115-269).

R. Jakobson List badacza polskiego, s. 666.

Omawiał je Josef Hrabák w Studium polského verše, "Slovo a slovesnost” 1936 R. 2, S. 122-123, i w recenzji z książki Siedleckiego Nová prace o polském verši, "Slovo a slovesnost” 1938 R. 4, S. 48-50.

61 Siedlecki do Kridla, list z 25 marca 1936 (LMAVB, F. 115-269). Artykuł Budzyka Metodologie stylistyky w Polsku (Pokus o charakteristiku a ocenění) ukazał się w praskim periodyku w1937 roku (R. 3, S. 139-155).

Informację podała Antonina Obrębska-Jabłońska w liście do Kazimierza Nitscha z Warszawy z 17 października 1945 roku, zob. Korespondencja Kazimierza Nitscha i Antoniny Obrębskiej-Jabłońskiej, cz. 1: 1925-1945, red. M. Skarżyński, E. Smułkowa, Księgarnia Akademicka, Kraków 2018, s. 598.

63 R. Jakobson List badacza polskiego, s. 666. 
a jedyny egzemplarz (czy może rękopisy), będący u Knisplówny, też uległ zniszczeniu"64. Po zażyłej intelektualnej współpracy pozostały: jeden arkusz drukarski, cztery rozprawy w maszynopisie, garść wspomnień i informacji w korespondencji zachowanej w archiwach ${ }^{65}$.

Przetrwał m.in. przekład Wskrzeszenia słowa Szkłowskiego dokonany przez Siedleckiego ${ }^{66}$. Spośród „świata polskich nowatorów" w literaturoznawstwie Jakobson cenił go najbardziej - chyba nie dlatego, że to on właśnie jako pierwszy informował w Polsce o jego pracach ${ }^{67}$. Raczej dlatego że Siedlecki odczytał je wyjątkowo wnikliwie, od razu wychwytując intencje ogólnoteoretyczne. Toteż nie dziwi, że do planowanego już w 1946 roku tomu prac Siedleckiego i prac o nim wstęp miał napisać właśnie Jakobson ${ }^{68}$. Mayenowa prosiła go o to ponownie rok później, w liście napisanym po rosyjsku z Pragi 30 marca 1947 roku, przedstawiając już szczegółowy plan publikacji ${ }^{69}$.

Jakobson wstępu do tomu, który ostatecznie ukazał się dopiero w 1975 roku już tylko z artykułami wprowadzającymi Mayenowej i Żółkiewskie$\mathrm{go}^{70}$, nie napisał. Siedlecki pozostawał jednak nieodmiennie w jego pamięci. Odpowiadając na zaproszenie Mayenowej, by przygotował rozprawę do zamyślanego przez nią encyklopedycznego zarysu poetyki, zaznaczał w liście z 14 marca 1958: „Chciałbym pracę moją poświęcić pamięci Siedleckiego

64 Korespondencja Kazimierza Nitscha i Antoniny Obrębskiej-Jabłońskiej, s. 589.

$65 Z$ dostępnej w archiwach wileńskim i nowojorskim korespondencji Kridla i Siedleckiego można jednak z dużym prawdopodobieństwem odtworzyć chronologię prac nad antologią i jej przypuszczalną zawartość. Z kolei z maszynopisów i rękopisów zachowanych we lwowskim archiwum Hopensztanda (Lwiwska Nacyonalna Naukowa Biblioteka Ukrainy im. W. Stefanyka) udałoby się odtworzyć przynajmniej część jego posłowia do antologii. Maszynopisy, uzupełniane odręcznie cytatami (np. z poezji Chlebnikowa), z których pierwszy został zatytułowany (ręką prawdopodobnie Hopensztanda) "Wstęp”, mają objętość około 60 stron.

66 Opublikowany dopiero w 1970 roku w antologii przygotowanej przez Mayenową i Zygmunta Saloniego, a dedykowanej Siedleckiemu Rosyjska szkoła stylistyki (PIW, Warszawa 1970).

67 F. Siedlecki Polska nauka o wierszu, "Wiadomości Literackie” 1933 nr 37; Roman Jakobson i nowa lingwistyka , "Wiadomości Literackie" $1934 \mathrm{nr} 43$.

68 Mayenowa pisała do Kridla w przywoływanym już liście z Pragi: „chcę wydać tom studiów Siedleckiego. Chcę, aby wstępną rozprawę napisał Jakobson".

69 O tym samym projekcie, ale pod inną redakcją - bez Mayenowej - planowanym jako tom drugi wznowionej po wojnie serii grupy warszawsko-wileńskiej „Z Zagadnień Poetyki” rok później Budzyk pisał Kridlowi w liście z Warszawy z 7 marca 1947 roku: „byłby pod red. Knisplówny i moją" i zawierał "wydanie zbiorowe" artykułów Siedleckiego" (RBML, Box 1). 
[...]". W opublikowanym w 1968 roku Liście badacza polskiego - a właściwie liście w liście: $\mathrm{w}$ artykule w formie listu adresowanym do „Drogiego Juliana” (Krzyżanowskiego), zawierającym list Siedleckiego wysłany z datą 3 lipca 1941 z okupowanej Warszawy, który otrzymał już w Nowym Jorku - nazywał go Przyjacielem, przez duże „P"11. Ten list bardzo poruszył Jakobsona. Zaraz po jego otrzymaniu donosił o nim w kartce do Kridla z 7 sierpnia 1941 roku, umawiając się z nim na telefon, a jeszcze lepiej na spotkanie, by pokazać mu pismo, „które niedawno dostałem od Siedleckiego"72. Cytował go w 1943 roku, w wykładzie w PIASA ${ }^{73}$. Mayenowa musiała o tym wiedzieć, skoro w liście do Jakobsona z kwietnia 1963 pisała: „Przesyłam ci fotografię Franka Siedleckiego. Może Ci się przyda kiedy. Zrobiłam ją w chwili ciężkiej dla nas: umarła przed miesiącem pani Wróblowa [czyli Stefania Knisplówna].Z jej fotografii powieliliśmy fragmenty naszej przeszłości dla nas"74.

Latem 1959 roku podczas obiadu w Konstancinie w domu rodziców Krystyny Pomorskiej Jakobson wzniósł pierwszy toast: „Wypijmy za pamięć Franciszka Siedleckiego"75.

\section{Role społeczne uczonego}

Wymienić je niełatwo. Na pewno wykraczają poza te przewidziane przez Floriana Znanieckiego w artykule $\mathrm{z} 1937$ roku Społeczne role uczonych a historyczne cechy wiedzy, rozwiniętym po trzech latach w książkę The social role of the man of knowledge $e^{76}$. Znaniecki, choć związany z najnowocześniejszą wtedy socjo-

R. Jakobson List badacza polskiego, s. 668.

RBML, Box 1, 2.

Wykład, jak już powiedziano, został opublikowany w formie artykułu Polish-Russian cooperation in the science of language. Jakobson cytuje w nim przejmujące słowa Siedleckiego, opatrując je wzmacniającym komentarzem: „«Wciąż żyjemy» - napisał wyjątkowy badacz z okupowanej Polski - «Warunki są trudne [...]. Ale jakoś się trzymamy!». Podkreślał, jak bolesne jest nie wiedzieć, co się stało z Praskim Kołem Lingwistycznym i z badaczami rosyjskimi, nie wiedzieć nawet, co go czeka i co czeka jego warszawskich przyjaciół" (s. 455).

Stefania Knisplówna (później Knispel-Wróblowa) opiekowała się Siedleckim w ostatnich dniach jego życia; por. K. Budzyk Stefania Knispel-Wróblowa (22. XI. 1911 - 2. II. 1963): wspomnienie, „Pamiętnik Literacki” 1963 z. 3.

S. Pomorski Remembering Roman Osipovič Jakobson, s. 266.

Artykułukazał się w „Przeglądzie Socjologicznym” 1937, s. 3-57, książka The social role of the man of knowledge w Nowym Jorku w 1940 roku. 
logią na Columbia University, nie przewidział, jakie role przyjdzie odegrać uczonemu emigracyjnemu wobec wspólnoty pozostałej w krajach od świata względnie izolowanych w połowie lat 30. i w latach 50.-70. Nie wziął pod uwagę, że główną wtedy formą kontaktu będzie korespondencja, rzadziej telefon, a nie dyskusje, ani domowe, na poły seminaryjne, ani oficjalne konferencyjne lub wokółkonferencyjne.

Że Jakobson spełniał wobec polskiego nowoczesnego literaturoznawstwa role intelektualne i dydaktyczne tzw. przez Znanieckiego scholara (autorytetu naukowego, wzorca rzetelności filologicznej, inicjatora i organizatora przedsięwzięć badawczych, inspiratora młodszych uczonych, dla których był wyrocznią i arbitrem, i to od lat 30., kiedy nie był jeszcze „wielkim Jakobsonem”), wynika z przywoływanej korespondencji. Że był jednym z konstruktorów polskiej teorii i jej najważniejszym międzynarodowym ambasadorem - także. Że był nauczycielem co najmniej trzech pokoleń polskich badaczy, wiemy. Że wiele ich pomysłów wynikało z jego prac, to oczywiste. Krótko: że odgrywał na polskiej scenie literaturoznawczej i poza nią role re ży s e ra, a k to ra i suflera jednocześnie, nie jest odkryciem.

Korespondencja, która ujawnia zakulisową aktywność Jakobsona, pozwala dodać do tych ról jeszcze inne. Zbiegają się one w najtrudniejszej może życiowej roli człowieka - roli przyjaciela. Nie tylko gwoli zadośćuczynienia konwencji pisał po jego odejściu Wiktor Weintraub: „Ze śmiercią tego wielkiego uczonego kultura polska traci swego szczególnie oddanego przyjaciela"77. Mayenowa w liście z kwietnia 1963 roku zapewniała, że skończy w tym roku swoją książkę - „choćby po to, by mieć na czym napisać: Romanowi Jakobsonowi". Zadedykowaną Jakobsonowi Poetykę teoretyczną ukończyła dopiero w roku 1974. Na jej płycie nagrobnej widnieje napis: „Maria Renata Mayenowa - filolog". Nie przypadkiem chyba prawie identyczny jak ten na płycie Jakobsona („Roman Jakobson - filolog rosyjski”). Praca filologa, jak pisał jeszcze w latach praskich, była jego ulubioną rolą.

By nie kończyć funeralnie, na co Jakobson żadną miarą nie zasługuje, do ról, które przez pół wieku pełnił wobec nowoczesnego literaturoznawstwa polskiego, trzeba dodać jeszcze jedną, w społeczności uczonych wcale nieczęstą. Był także nauczycielem humoru: specyficznego, wyrafinowanego intelektualnie, dostępnego nielicznym. Sam zgłębiał tajniki ludycznego zachowania naukowego w latach rosyjskiej młodości, we własnej praktyce artystycznej i naukowej - czy to publikując w roku 1916 pozarozumowe wiersze

77 W. Weintraub Roman Jakobson, "Tygodnik Powszechny" 1983 nr 1. 
we wspólnej z Kruczonychem Zaumnoj gnigie, czy to tłumacząc w roku 1918 na starocerkiewnosłowiański wiersz Majakowskiego Nie ponimajut i zarazem rekonstruując w tym cudacznym przekładzie wersyfikację słowiańską, czy też analizując „sprośną śpiewkę" (cantilena inhonesta) - erotyk żakowski z XV wieku $^{78}$. W Polsce dał popis tego intelektualnego humoru w roku 1960 na pierwszej Międzynarodowej Konferencji Poetyki. Podczas kolacji, po dyskusji ze Stefanią Skwarczyńską, rozpoznał mianowicie „potrzebę naukowej historii sztuki kulinarnej". Rezultatem był Szczupak po polsku ${ }^{79}$. Jakobson zanalizował najstarszy w języku czeskim zbiór porad kucharskich z drugiej połowy XV wieku i pierwszą czeską książkę kucharską z lat 20. lub 30. wieku $\mathrm{XVI}^{80}$. Doszedł do głęboko strukturalistycznego wniosku: „W systemie gastronomii czeskiej XVI-XVII wieku [...] dania polskie [...] pełnią specjalną [...] funkcję", który rozwinął w historyczno-kulturową konkluzję o poetyce gotyckiej czeskiego kucharzenia i poetyce romańskiej - polskiego. Uczone rozważania zakończył wezwaniem: „Ileż zajmujących odkryć [...] obiecuje [...] eksperyment z ponownym wypróbowaniem przepisów zachowanych w średniowiecznych książkach z różnych krajów Europy"81.

78 Opublikowaną przez Jakobsona w 1935 roku wykładnię "śpiewki” jako utworu śląsko-polskiego z wtrętami czeskimi, przez blisko 70 lat funkcjonującą jako autorytatywna (Slezsko-polská cantilena, "Národopisný věstník českoslovanský” 1934/1935 R. 37/38, s. 56-84), podważył Jacek Baluch, dowodząc, że jest to tekst czeski z licznymi polonizmami. Wzorem Jakobsona przeprowadził nie tylko nienaganny dowód filologiczny, ale dał też przedni, wsparty na poetyce folkloru przekład utworu na współczesną polszczyznę (). Baluch Zamazany inkaustem rękopis czyli śląsko-czeska sprośna śpiewka, Scriptum, Kraków 2013).

79 Artykuł Szczupak po polsku po raz pierwszy ukazał się w dedykowanym Stefanii Skwarczyńskiej tomie 20 łódzkich "Prac Polonistycznych" - periodyku, który uczona stworzyła - z 1965 roku; cyt. za przedrukiem w: R. Jakobson W poszukiwaniu istoty języka. Wybór pism, wybór, red. i wstęp M.R. Mayenowa, PIW, Warszawa 1989, t. 1, s. 100.

80 Jakobson żywo interesował się dawnymi utworami ze śląsko-polsko-czeskiego pogranicza. Ultrafioletowe fotografie potrzebnych mu tekstów otrzymał od Jerzego Woronczaka, o czym często wspominał w listach do Mayenowej z lutego-kwietnia 1958 roku. 


\section{Abstract}

\section{Danut Ulicka}

UNIVERSITY OF WARSAW

The Social Roles of Scholars: Roman Jakobson and the Poles

Ulicka explores the status of the archival source ("the hard fact") in intellectual history. She demonstrates that only the letter is such a"fact," since, in contrast to memoirs, diaries and journals, it can be neither edited nor replaced. Material supporting this argument consists of the corpus of the correspondence of Roman Jakobson and Maria Renata Mayenowa, as well as letters exchanged between Jakobson and Polish literary scholars in the interwar and postwar years. They reveal the backstage history of theoretical poetics and other forms of literary scholarship, including most importantly the enduring penfriendships that were forged in the 1930 s across disciplines and national borders and that impacted emerging concepts.

\section{Keywords}

letter, archive, hard fact, intimacy, official and unofficial history of science, collegium invisibile 